\title{
Effectiveness of the WebQuest Strategy-Based Educational Platform and Learning Environment in Acquiring Biological Concepts and Systemic Thinking in the Biology Course among Pre-Service Teachers
}

\author{
Tahani Alebous \\ World Islamic Science and Education University, Amman, Jordan \\ https://orcid.org/0000-0002-9938-2859
}

\begin{abstract}
This study aims at uncovering the effectiveness of the WebQuest strategy-based learning environment in the teaching of biological concepts and imparting of systemic thinking. The participants of the study, 64 pre-service teachers (students) for the 2020-2021 academic year, were divided randomly into experimental and control groups. WhatsApp groups were used to communicate with the students. To achieve the study's objectives, a teacher's manual for biological concepts was prepared following the WebQuest Model; the WebQuests were created using the Zunal computer programmes. Both biological concepts and systemic thinking assessments were prepared and the study tools were tested for accuracy and reliability. To answer the research questions, data were analysed using ANCOVA and MANCOVA. There were significant differences between the average performances of the two study groups on the scale of the acquisition of biological concepts in favour of the experimental group. Additionally, there were significant differences between the average performances of the groups on a scale of systemic thinking in favour of the experimental group. The results encouraged the educational supervisors to hold training courses and workshops for science teachers, training them in the use of the WebQuest strategy in science teaching and urging its implementation in teaching through individual instruction and publications. The Ministry of Education must play a role in designing and writing the science curricula and provide a guide for the teachers explaining the ways to employ the WebQuest strategy in the process of teaching science.
\end{abstract}

Keywords: educational platform; WebQuest; biological concepts; systemic thinking; biology

\section{Introduction}

Due to the prevailing coronavirus pandemic, severe challenges hinder the learning process which - additionally - coincide with the increase in knowledge, sciences, and technological revolution. Education must progress from passive 
learning to utilising technology and e-learning to enrich students' options, facilitate the building of sound concepts, support the willingness to learn, and instil and deepen learning values.

Under the new outlook of the learning process, grasping scientific concepts is crucial to retaining the fundamentals and main functions of any science. The American Association for the Advancement of Science (AAAS) considers the sound understanding of different scientific concepts as one of the main components of scientific culture for any individual, as it aids in making decisions and managing the issues of life (AAAS, 1993). Educational studies and research results in the field of science education highlighted certain difficulties in learning and acquiring scientific concepts - students often develop several misconceptions around the mechanisms of biological processes at the molecular level (Zuckerman, 1994). A few studies indicated that many secondary school and university students hold misconceptions about the main concepts of biology, such as osmosis and diffusion (Odom, 1995). They do not possess the right understanding of scientific concepts since most are not taught the correct scientific mental schemes and, thus, resort to memorising science subjects to pass exams (She, 2002) and (Yang et al., 2003). Students practice skills such as organisation, association, differentiation, defining common characteristics, abstraction, and defining major and minor characteristics in the process of acquiring scientific concepts. These skills are necessary in developing students' systemic thinking, which has become one of the goals of teaching science. Therefore, modern science curricula tend to be a major tool in expanding students' thinking, in addition to linking the thinking process with their performance skills.

Arnold and Wade (2015) argued that using systemic thinking skills enable the adequate understanding of the root cause of some complex behaviours in order to better predict them and regulate their results. Furthermore, there is an increased need for systemic thinkers to solve complex problems. The need for systems thinkers to deal with convoluted problems has increased, and this need extends beyond the fields of science and engineering to include all aspects of life. Hence, to prepare for an increasingly complex future, people in decision-making roles must have a strong understanding of systems thinking. The interest in organising educational subjects on a basis that ensures the development of systemic thinking skills by synthesising various parts of any system is considered an essential prerequisite for outputs corresponding with the objectives of the learning process. Abd and Mohammad (2017) asserted that a large percentage of science teachers are not interested in developing students' systemic thinking skills, which negatively affect their performance. To sustain the pace of the noticeable development in science curricula, teaching methods and strategies were developed to emulate global trends concerning the preparation of graduates who will be capable of dealing with the challenges of this era. Most prominently, the e-learning method allows for an interactive environment that suits students' needs and increases their self-confidence which is regarded as a pivotal point in the learning process. Dodge, in 1995, brought the idea of the WebQuest strategy to light. Dodge (2001) explains that a WebQuest is an activity based on investigation, through which students participate in an interactive predefined task using available resources on the internet. The nature of this strategy allows 
students to use their skills to solve problems and engage with primary information resources as opposed to secondary resources. A WebQuest is considered an important strategy in the field of education as it helps students in research and investigation, encouraging them to develop various skills.

This study has applied the WebQuest strategy in teaching biology to bachelor's degree students, whereas the whole world is now moving towards applying it in various other subjects. The researcher believes that the learning of biological concepts and development of systemic thinking occur as a natural consequence of some real practices during e-learning through an educational platform and the Microsoft Teams application. The changes in society during the coronavirus pandemic call for alterations in the learning process. Even at the undergraduate level - in an information technology era, the need for a shift in the learning process to shape students has become imminent to meet the needs of the era. WebQuests emerged because interactivity surpasses negative learning and takes students to new horizons, enabling them to take responsibility for learning as well as build and acquire knowledge, resulting in a deeper and richer comprehension and the enrichment of thinking methods due to its consistency with the constructivism theory of knowledge (Quinn \& Wild, 1998). The WebQuest strategy via the internet is one of the most important practical applications of constructivism theory, changing the role of the teacher from a transmitter of knowledge to a facilitator of the educational position. The teacher prepares the educational material and sets the necessary instructions, allowing students to engage in selflearning (Bayram et al., 2019; Ulu \& Ulusoy, 2010). WebQuests play an important role in improving the way students learn as individuals in this environment are exposed to the subject in different ways. Hence, this study is significant because it measures the impact of an educational platform and learning environment based on the WebQuest model on the learning of biological concepts and acquisition of systemic thinking at the university level. The WebQuest strategy are also consistent with constructivist theory in its view of content as content, according to cognitive journeys, is no longer limited to writers but rather the student attains knowledge through his interaction with the virtual content (Gurgil et al., 2019).

The WebQuest strategy is characterised by their simulation of students' preferences and interests as well as the colours and images stimulating their interests and motivating them to learn (Badmus et al., 2019).

\section{Problems}

The research problem arises from the on-going situation in Jordan's higher education system. Despite what is described as the knowledge revolution era in life sciences, some of the concepts related to biology are difficult to understand due to the high level of abstraction and difficulty in envisioning their mechanisms, which lead students to several misconceptions about the mechanisms of biological processes at the molecular level (Zuckerman, 1994; Odom, 1995). Additionally, students do not have appropriate scientific schemes for concepts (She, 2002) and, therefore, resort to memorising the subject (Yang et. al, 2003). In relation to some scientific concepts, the researcher noticed that many pre-service teachers suffer from weaknesses in scientific courses and display negative attitudes towards 
learning them. About $90 \%$ of the pre-service teachers postpone scientific courses to the fourth (final) year of the program. Moreover, most of them do not choose the scientific stream in high school. Hence, the research problem lies in the urgent need to intensify efforts to increase students' level of performance in science courses such as biology, pursue high-quality learning outputs, and prepare them before graduation in a way that positively reflects on their future students once they become immersed in teaching primary school classes. This has shaped the problem of this study that seeks to uncover the effectiveness of the WebQuest model-based learning environment for teaching biology and developing systemic thinking skills in pre-service teachers. This study aims to answer the following two questions:

1. How effective is the WebQuest strategy-based learning environment in acquiring biological concepts by pre-service teachers in the biology course?

2. How effective is the WebQuest strategy-based learning environment in developing systemic thinking skills in pre-service teachers in the biology course?

\section{Objectives of the Study}

- Employing the WebQuest strategy in improving biological concepts and systemic thinking among class teacher students during the COVID-19 pandemic

- Investigating the existence of statistically significant differences in the averages of systemic thinking and biological concepts between the experimental group and the control group students attributed to the use of the WebQuest strategy in teaching biology compared to the usual methods

\section{Significance of the Study}

The significance of this study stems from the value of the subject it covers, namely, biological concepts and pre-service teachers' systemic thinking in the biology course. It sets forth two psychometric measurement tools and technology based on e-learning, which may be of benefit for future research. Further, it proposes a theoretical framework and practical application of WebQuests for teaching biology to impart scientific concepts and develop systemic thinking at an undergraduate level. This study may provide those in charge of qualifying and updating teachers with new information and technology contributing to creating training programs and improving the competence of future teachers. It can potentially open new horizons for researchers in this field.

\section{Limitations}

This study was conducted through Microsoft Teams and Zunal as part of the biology course and its teaching methods in the first semester of the 2020-2021 academic year for pre-service teachers. The study is limited by the measuring tools in terms of accuracy and reliability indicators as well as the objectivity of respondents. 


\section{Procedural Definitions}

WebQuests: Jaqueline (2007) defined them as learning activities that rely on web search activities in the first place to find information efficiently and aims at improving and developing in students many mental capabilities (comprehension, analysis, synthesis, etc.). Operationally, it is defined as a group of student activities through web searches, available through a designed website that contains lessons constructed in accordance with Dodge (1995) and March's (2003, 2004) educational model, consisting of five stages (presentation, tasks or activities, implementation or operations, evaluation, conclusion). The aim lies in searching for necessary information in biology topics such as plant reproduction, organism classification as well as human body systems. It contains original and real problems that motivate biology students/pre-service teachers to investigate and search for a participatory and collaborative learning environment.

Scientific Concepts: It is defined as "a term encompassing a group of existing ideas that are generalised from certain events, observations or situations; and it is a mental structure resulting from understanding the common relationships or characteristics between phenomena, events or things" (Zuytoon, 2007, p. 481). Biological concepts are operationally defined as mental representations resulting from understanding the relationships and components of plant reproduction, organism classification, and human body systems which are expressed by a certain scientific term within the topics, of which biology students/pre-service teachers will learn, according to WebQuests and traditional learning methods. Acquiring an understanding of these concepts was measured by the grades achieved by students in the assessment of the biological concept prepared for this study.

Systemic Thinking: It is an individual's ability to form visualisations and models consisting of a group of interlinked elements and components (Afana et al., 2007, p. 10). Its predetermined skills in this study are: dissecting main systems to subsystems skills, recognition of intersystem relationships, bridging gaps in the system, and synthesising systems from their components. These skills are measured by the overall grade achieved by students in the systemic thinking skills assessment prepared by the researcher.

Pre-service Teachers: They are undergraduate students in their third and fourth years of the program in the 2020-2021 academic year.

\section{Theoretical Frame \& Previous Studies}

Web stands for websites and Quest stands for search. Hence, WebQuests refer to searching for information on the internet. They are learning activities based on internet search which enable the individual to acquire information adequately and efficiently. Mitchell (2003) believes that the rise of WebQuests enables the optimum use of the internet when searching for information for educational purposes, whereas using search engines such as Google and Yahoo may return a vast number of results which could distract students and exhaust time. This strategy is an organised web environment that helps in learning through primary resource links as well as original tasks motivating students to search and 
investigate in a participatory and collaborative manner to achieve meaningful learning and develop their mental capabilities.

The International Society for Educational Technology elucidated that the WebQuest strategy is one of the most important teaching strategies based entirely on modern technologies and one of the most important applications of constructivist theory (International Society for Technology in Education, 2020)

The WebQuest strategy via the internet is one of the most important practical applications of constructivism theory. It has changed the role of the teacher from a transmitter of knowledge to a facilitator of the educational position. The teacher prepares the educational material and sets the necessary instructions, allowing students to engage in self-learning (Bayram et al., 2019; Ulu \& Ulusoy, 2010).

The WebQuest strategy is based on educational theories such as Piaget's theory of knowledge: when students acquire knowledge, they incorporate it effectively to attain cognitive balance, unlike in the case of negative learning, resulting in cognitive development and building relevant experiences; Vigotsky's social constructivist theory: acquiring knowledge through encouraging group collaboration and sharing opinions and ideas to develop the students' mental capabilities and research skills and obtain information effectively on the internet (Fargoun, 2014).

The nature of behaviourism displays its impact on WebQuests by engaging students with tasks along with words of encouragement through the stages of the quest, followed by the students' responses to these tasks by utilising available website links. There are two types of WebQuests depending on the predefined time to complete them, assigned tasks, and students' computer literacy (Dodge, 2001, 2011):

Type 1: short-term WebQuests that range between 1-4 lessons, mainly focusing on one subject. This type is used for students with beginner-level computer skills; the aim is to find information sources, understand, and recall them.

Type 2: long-term WebQuests that range between 2-4 weeks, revolving around questions that require advanced cognitive processes such as analysis, synthesis, and evaluation; here, students are asked to complete advanced tasks using HTML coding language, image processing software (Photoshop), or presentation software (PowerPoint). This study will implement long-term WebQuests due to its suitability for the university undergraduate level.

Hassanien (2006) sets forth seven key elements for creating WebQuests:

1. Introduction: This contains a preamble that raises students' motivation through interesting images that fit the WebQuest topic.

2. Task: This defines the required final result that students must accomplish with the aim of learning the scientific subject in question. It is considered a pivotal point for students to begin their quest.

3. Process: This part of the activity defines the steps of task completion by providing instructions, guidance, and tips. It involves dividing students into groups, distributing the workload among them, and setting deadlines. 
4. Resources: These specify carefully picked and trustworthy websites that suit students' level of experience by the teacher who designs the WebQuest.

5. Evaluation: This establishes a set of standards to evaluate students, which include research methods, taking responsibility, distributing tasks, and presenting results.

6. Conclusion: This summarises learning outcomes, reminds students of the acquired skills, encourages them to benefit from the results they find, and to use communication to acquire knowledge.

7. Teacher's page: This is added after the conclusion of the WebQuest for other teachers to benefit from it.

Our educational system is lacking when it comes to students' ability to use knowledge in solving daily problems that they face, especially scientific problems that occur in the world and successive scientific changes requiring scientific subjects, such as physics and chemistry, to focus attention on the practical side of knowledge which entails utilising audio, video, and explanatory drawings of scientific phenomena. This can be achieved through a set of strategies based on technology overall, especially computers. One of these strategies is WebQuests, which provides a suitable environment for learning due to what it achieves in terms of gaining scientific thinking skills through educational tasks, based on questions that promote self-learning and adequate navigation of information sources.

Ikpeze and Boyd (2007) stated that WebQuests help improve learning, crucial to students' acquiring advanced scientific thinking skills. Further confirming this, Mitchell (2003) concluded that WebQuests play a role in improving learning, positively affecting the students' attitudes and use of the internet. Amini et al. (2020) concluded that WebQuests provide teachers and students with many collaboration opportunities, thereby making the learning experience meaningful, empirical, and motivating.

Ismael and Abdo (2008) sought to measure the impact of using WebQuests on developing thinking styles and the shift towards using them for teaching science to students in the faculty of education. It was an empirical study where 76 students from the pre-service teacher faculty at King Abdulaziz University in Jeddah were chosen for the experimental group and 68 students were chosen from the pre-service teacher faculty at King Khalid University in Khamis Mushait to represent the control group. The study tools consisted of the thinking styles test and attitude scale. The study indicated the following:

1. There was a statistically significant variance $(\alpha=0.01)$ between the arithmetic means of grade marks for the experimental and control groups using the thinking styles test in favour of the experimental group, implying considerable growth and improvement in the level of subgrades of the test as a result of experiencing the WebQuest.

2. A statistically significant variance $(\alpha=0.01)$ was observed between the arithmetic means of experimental group grades in the before and after of the application of the attitude scale in favour of the experimental group as a result of experiencing the WebQuest. 
The results of the study conducted by Salih (2014) confirmed that WebQuests increase students' performance and develop fundamental thinking skills.

The term scientific concept has a specific meaning and it requires understanding the relationships between things, phenomena, and information that are linked to each other. Forming and developing scientific concepts is one of the most important aims of teaching science as it helps in understanding the subject and advancing the effects of learning. This requires the use of educational styles and strategies that revolve around students with varying capabilities in order to ensure learning and retention of scientific concepts (Ralph \& Collen, 2008).

The researcher believes that the most relevant property of concepts is that it grows with individuals, and knowledge grows with the growth of concepts. Concepts increase in difficulty from one stage (age) to the next and depend on students' previous experiences - which differ among individuals. Concepts can be considered as thinking tools that assist in dealing with the facts around us.

The first stages of systemic thinking started to appear in 1940 - a new concept from the hands of Jay Foster. Arthur and Steaven (2015) defined systemic thinking as a mental process that visualises systems, with their components strongly interconnected and linked. Mastering our understanding of how things operate lies in explaining the interrelations and interactions between and within systems.

Ali (2009) indicated that the birth of biological sciences in the early 1900s by the Austrian scientist Ludwig Von Bertallanffy was a driving force in developing systemic thinking because these sciences describe organisms as complex systems consisting of interconnected subgroups for survival. He believes that this thinking could also be applied to organisms that are exposed to inputs in a changing environment. Inputs are then converted to outputs such as activities, behaviours, and products, called the General Systems Theory (GST). Systemic thinking is considered to fall under Gestaltism as it involves thinking about parts of the situation and their interrelationship and interactions with each other. This pattern of thinking differs from conventional patterns of thinking in that it combines analytical and synthetic thinking (Stephen, 2009). Systemic thinking is closely related to the constructivism theory as it assumes that students build on their knowledge and form relevant systems through interactions from previous and novel experiences, which results in constructing meaning according to knowledge backgrounds and awareness of systems that can be constructed and analysed based on the available forms of illustration (Al-Kamel, 2004). To overcome cognitive divergence between parts of a phenomenon or subject and isolation from the system to which they belong, systemic thinking handles the elements of the phenomenon comprehensively without discounting any of its particulars (Sarid, 2013). It is also an effective method that aids students to broadly and comprehensively envision systems and form an appreciation for its elements, patterns, and different cycles. It also assists with uncovering the real causes of problems within systems and identifying an appropriate starting point for these problems (McNamara, 2006). 
In the educational context, systemic thinking has a great impact on sustainable development as it assists in teaching systems' dynamics and observing the development of systemic thinking in terms of thinking processes and learning progress. There are some advantages of using visual illustrations of causal relationships as an easy method of systemic illustration. Moreover, learning systemic thinking illuminates the value of forms and methods of systemic illustrations. Therefore, identifying systemic illustration tools (i.e., illustrative diagrams of casual relationships) and ways of dealing with them are the main considerations for learning systemic thinking (Ossimitz, 2014). Systemic thinking plays a crucial role, according to Judi (2004), and some of the roles are summarised as follows: problem simplification and interaction between a system's parts enable students to clearly envision their properties, effects, and various relationships. This aids students in developing capabilities to analyse and synthesise with flexibility despite the various methods of achieving objectives and acquiring metacognition skills, and cognitive, emotional, and psychomotor learning experiences systematically and holistically. On the other hand, Assaraf and Orion (2010) suggested that systemic thinking skills could be further particularised with such ability to identify elements and components within systems, identify dynamic relationships between these components, organise components and relationships within a particular system, and the ability to make generalisations, understand the circular and repetitive nature of systems, review past events, and predict the future.

The study conducted by Al-Ghamdi and Al-Afshi (2018) aimed to determine the effectiveness of a participatory e-learning environment in developing critical thinking skills for Princess Nourah bint Abdulrahamn University students. To achieve the objectives of this study, the semi-empirical method was used. The survey sample included 12 students divided into experimental and control groups. The results of the study presented a lack of statistically significant variance between the two groups in critical thinking, identifying assumptions, evaluating discussions, explanation and deduction assessments, which is attributed to the teaching method. On the other hand, the study conducted by Jumaa and Ahmad (2012) sought to identify the effectiveness of WebQuest strategy-based teaching on the academic achievement of third-year chemistry students of the University of Sulaimani. The survey sample was selected from a class of 65 students, out of which 40 were randomly selected and equally divided into experimental and control groups by flipping a coin. This study tool was an achievement test. It concluded that the WebQuest-based teaching strategy was effective in the academic achievement of the third-year chemistry students in the subject of biochemistry.

Additionally, Badmus et al. (2019) conducted a study aimed at identifying the use of the WebQuest strategy via the web in the acquisition of science concepts by students in Nigerian schools; to achieve the goal of the study, the use of an achievement test and the selection of the study sample (48 students) were randomly divided into a group with proven results. There were differences found in the experimental group. 


\section{Methodology}

The quasi-experimental approach was used due to its suitability for this study.

\section{Study Sample:}

The sample consisted of 64 intentionally selected students from first semester preservice bachelor's degree students for the 2020-2021 academic year from two classes in the World Islamic Sciences and Education University. They were randomly divided into an experimental group (30 students) and control group (34 students). The experimental group was taught using WebQuests while the control group was taught following the traditional manner.

\section{Study Tools:}

I. Biological concepts test: this assessment was prepared for biology and its teaching methods course. The researcher chose the following topics: plant reproduction, cell division, organism classification, and human body systems. The learning outcomes were specified and their cognitive, emotional, and skill-based aspects were clarified. A preliminary version of the assessment containing 25 questions was peer-reviewed and a final version containing 22 questions was adopted, taking into consideration the suggestions made by the reviewers to delete some questions and edit some others for clarity. A pilot study was conducted on 30 pre-service bachelor's degree students to measure the length and reliability of the assessment as well as the difficulty coefficient and discriminant index of the questions. The difficulty coefficient results ranged between $0.45-0.80$ which is considered acceptable and allows for differentiation between students, further confirmed by the discriminant index values ranging between $0.20-0.62$ - also an acceptable level for the study. The pilot study was conducted a second time two weeks after the first on the same group - namely grade 9 school students - to ensure the reliability of the assessment. The correlation coefficient between the results from the two pilot studies was 0.82 , a stable and suitable level for this study.

II. Systemic thinking: relevant research literature and studies, such as AlAklouk (2010) and Siam (2017), were reviewed. Afterwards, the assessment questions were written and constructed to measure the pre-service teachers' capability to develop systemic thinking skills. The assessment consisted of 20 multiple-choice questions covering systemic thinking skills where only one out of four answers was correct. Four skills were specified: dissecting a primary system into subsystems, comprehending relationships within the system, bridging gaps inside the system, and synthesising systems out of their components. A preliminary version of the assessment was peerreviewed to ensure the accuracy of the assessment by 13 specialists - some were university science professors and the rest school science teachers. Based on their suggestions, some questions were removed, some replaced with other questions, and some drawings and shapes amended to make them more intelligible. To ensure the reliability of the assessment, the reliability coefficient was measured using the test-retest method. A pilot study was conducted on 30 pre-service teachers, who retook the test after two weeks. The internal consistency reliability coefficient was measured using 
Cronbach's alpha at 0.808 , which was considered a suitable level for this study.

\section{Results}

Question 1: Is there any statistically significant variance in the arithmetic means of grade marks between the experimental and control groups in the measure of acquiring scientific concepts that can be attributed to the implementation of the WebQuest strategy?

Arithmetic means and standard deviations were calculated for the grade marks of both groups. The students took the test once before and once after learning, as can be seen in Table 1.

Table 1: Arithmetic Means and Standard Deviations of Academic Achievement of Both Groups in the Assessment of Acquiring Scientific Concepts in both the Pre- and Post-learning Tests

\begin{tabular}{|r|r|r|r|r|r|r|}
\hline \multicolumn{2}{|c|}{ Post-learning Test } & \multicolumn{2}{|c|}{ Pre-learning Test } & Max & No. & Group \\
\hline SD & $\mathrm{M}$ & $\mathrm{SD}$ & $\mathrm{M}$ & & & \\
\hline 2.37 & 16.29 & 3.23 & 9.56 & \multirow{2}{*}{22} & 34 & Experimental \\
\hline 3.26 & 9.83 & 2.85 & 7.23 & & 30 & Control \\
\hline 4.29 & 13.27 & 3.25 & 8.47 & & 64 & Total \\
\hline
\end{tabular}

Table 1 displays an apparent variance between the arithmetic means of the two groups in the study during the post-learning assessment of acquiring scientific concepts. The experimental group which taught using WebQuest's strategy scored an average of "16.29", whereas the control group which taught using the traditional method scored an average of "9.83". The covariance analysis (ANCOVA) was performed "at the $\alpha=0.05$ significance" level to confirm that the variance between the group averages is statistically significant. The results are presented in Table 2.

Table 2: ANCOVA Results for Variance in Academic Achievement of Both Groups in the Post-learning Test of Acquiring Scientific Concepts

\begin{tabular}{|r|r|r|r|r|r|r|}
\hline $\begin{array}{r}\text { Eta } \\
\text { squared }\end{array}$ & Sig. & F & MS & Df & SS & Source of Variation \\
\hline & 0.001 & 12.783 & 85.453 & 1 & 85.453 & Pre-learning Concepts Acquiring \\
\hline 0.513 & 0.000 & 64.348 & 430.152 & 1 & 430.152 & Teaching strategy \\
\hline & & & 6.685 & 61 & 407.773 & Error \\
\hline & & & & 63 & 1158.484 & Corrected Total \\
\hline
\end{tabular}

Table 2 depicts the $(F)$ value $(64.348)$ at the $(\alpha=0.000)$ significance level for the variance between the academic achievement of the groups in the post-learning assessment for acquiring scientific concepts, indicating a statistically significant variance. The corrected means and standard errors for the groups' academic achievements were calculated to identify which one was favoured by the variance. Table 3 points out the variance. 
Table 3: Corrected Means and Standard Errors of the Groups' Academic Achievement in the Post-learning Assessment for Acquiring Scientific Concepts

\begin{tabular}{|r|r|r|r|r|}
\hline Std. err. & Corrected Mean & $\max$ & No. & Group \\
\hline 0.46 & 15.88 & & 34 & Experimental \\
\hline 0.49 & 10.31 & 22 & 30 & Control \\
\cline { 1 - 3 } & & &
\end{tabular}

Table 3 illustrates that the experimental group taught using WebQuests had a corrected mean (15.88), while the traditionally taught control group had a controlled mean (10.31). This indicates that the variance is in favour of the experimental group, confirming that the WebQuest strategy-based learning environment is effective in acquiring biological concepts for pre-service teachers in the biology course. This is further confirmed by the eta-squared value $(0.513)$ signifying the scale of the WebQuest strategy's impact in acquiring scientific concepts. More specifically, $51.3 \%$ of the variance in acquiring scientific concepts is due to the WebQuest strategy. The other $48.7 \%$ of the variance is due to other variables outside the scope of this study.

Question 2: Is there a statistically significant variance between the arithmetic means of pre-service teachers' grade marks in the experimental group and control group in developing systemic thinking skills which can be attributed to the use of WebQuests?

To answer this question, arithmetic means and standard deviations were calculated for the grade marks of both groups in the pre- and post-learning systemic thinking assessments. This is demonstrated in Table 4.

Table 4: Arithmetic Means and Standard Deviations of Academic Achievement of Both Groups in the Assessment of systemic thinking in both the Pre- and Postlearning Test

\begin{tabular}{|c|c|c|c|c|c|c|}
\hline \multicolumn{2}{|c|}{ Post-learning Test } & \multicolumn{2}{|c|}{ Pre-learning Test } & \multirow{2}{*}{ Max } & \multirow{2}{*}{ No. } & \multirow{2}{*}{ Group } \\
\hline SD & $\mathbf{M}$ & SD & $\bar{M}$ & & & \\
\hline 2.41 & 13.29 & 3.69 & 7.15 & \multirow{3}{*}{20} & 34 & Experimental \\
\hline 2.18 & 6.23 & 2.18 & 4.70 & & 30 & Control \\
\hline 4.22 & 9.98 & 3.29 & 6.00 & & 64 & Total \\
\hline
\end{tabular}

Table 4 depicts an apparent variance in the arithmetic means of the two groups based on the academic achievement on the post-learning assessment of systemic thinking. The experimental group was taught using the WebQuest strategy scoring an average of 13.29, while the control group using the traditional method scored an average of 6.23. ANCOVA was performed at the $a=0.05$ level of significance to ensure that the variances between the two group averages are statistically significant. The results are presented in Table 5. 
Table 5: ANCOVA Results for the Variance between the Two Groups' Averages of Academic Achievement in the Post-learning Systemic Thinking Assessment

\begin{tabular}{|r|r|r|r|r|r|r|}
\hline $\begin{array}{r}\text { Eta } \\
\text { Squared }\end{array}$ & Sig. & F & MS & Df & SS & Source of Variation \\
\hline & 0.000 & 14.182 & 61.953 & 1 & 61.953 & $\begin{array}{r}\text { Pre-learning Systemic } \\
\text { Thinking }\end{array}$ \\
\hline 0.669 & 0.000 & 123.181 & 538.102 & 1 & 538.102 & Teaching Strategy \\
\hline & & & 4.368 & 61 & 266.472 & Error \\
\hline & & & & 63 & 1122.984 & Corrected Total \\
\hline
\end{tabular}

Table 5 exhibits the F value (123.181) for the variance in the academic achievement of the two groups in the post-learning systemic thinking assessment, which is a significant value at a confidence level $(\alpha=0.000)$. Hence, the variance in the academic achievement of the two groups in the post-learning systemic thinking skills assessment is statistically significant. The corrected means and standard errors of the academic achievement were calculated to identify which group was favoured by the variance. Table 6 reveals the variance.

Table 6: Corrected Means and Standard Errors of the Groups' Academic Achievement in the Post-learning Systemic Thinking Assessment

\begin{tabular}{|r|r|r|r|r|}
\hline Std. err. & Corrected Mean & Max & No. & Group \\
\hline 0.37 & 12.92 & \multirow{2}{*}{20} & 34 & Experimental \\
\cline { 1 - 2 } \cline { 5 - 6 } & 6.40 & & 30 & Control \\
\hline
\end{tabular}

Table 6 shows that the experimental group - taught using the WebQuest strategy -achieved a corrected average of 12.92, while the control group which taught using a traditional method achieved a corrected average of 6.66 , indicating a variance in favour of the experimental group. This confirms that the WebQuest strategy-based learning environment was effective in systemic thinking for preservice teachers in the biology course. This result is further confirmed by the Eta squared value (0.669) which signifies the scale of impact of this strategy in systemic thinking. In other words, $66.9 \%$ of the variance in developing systemic thinking is attributed to the teaching strategy and the rest of the variance (33.1\%) is due to other variables outside the scope of this study. Moreover, the arithmetic means and standard deviations of the academic achievement in the post-learning assessment for both groups were subdivided based on the specific skills. The results are displayed in Table 7.

Table 7: Arithmetic Means and Standard Deviations for the Academic Achievement of Both Groups in All Skills Assessed Pre- and Post-Learning

\begin{tabular}{|c|c|c|c|c|c|c|c|}
\hline \multicolumn{2}{|c|}{ Post-learning } & \multicolumn{2}{|c|}{ Pre-learning } & \multirow{2}{*}{ Max } & \multirow{2}{*}{ No. } & \multirow{2}{*}{ Group } & \multirow{2}{*}{ Skills } \\
\hline SD & $\mathbf{M}$ & SD & $\mathbf{M}$ & & & & \\
\hline 1.39 & 3.79 & 1.38 & 1.56 & \multirow{3}{*}{6} & 34 & Experimental & \multirow{3}{*}{$\begin{array}{r}\text { Dissecting } \\
\text { Primary Systems }\end{array}$} \\
\hline 1.21 & 1.83 & 1.10 & 1.43 & & 30 & Control & \\
\hline 1.63 & 2.88 & 1.25 & 1.50 & & 64 & Total & \\
\hline 0.83 & 2.18 & 1.02 & 1.53 & \multirow{2}{*}{3} & 34 & Experimental & \multirow{2}{*}{$\begin{array}{r}\text { Understanding } \\
\text { Relationships }\end{array}$} \\
\hline 0.79 & 1.00 & 0.85 & 0.90 & & 30 & Control & \\
\hline
\end{tabular}




\begin{tabular}{|c|c|c|c|c|c|c|c|}
\hline 1.00 & 1.63 & 0.99 & 1.23 & & 64 & Total & \\
\hline 1.75 & 4.82 & 1.95 & 3.00 & \multirow{3}{*}{7} & 34 & Experimental & \multirow{3}{*}{$\begin{array}{l}\text { Bridging Gaps } \\
\text { Within Systems }\end{array}$} \\
\hline 1.29 & 2.30 & 1.37 & 1.83 & & 30 & Control & \\
\hline 2.00 & 3.64 & 1.79 & 2.45 & & 64 & Total & \\
\hline 1.02 & 2.50 & 1.04 & 1.06 & \multirow{3}{*}{4} & 34 & Experimental & \multirow{3}{*}{$\begin{array}{r}\text { Synthesising } \\
\text { Systems' } \\
\text { Components }\end{array}$} \\
\hline 1.03 & 1.10 & 0.82 & 0.53 & & 30 & Control & \\
\hline 1.24 & 1.84 & 0.97 & 0.81 & & 64 & Total & \\
\hline
\end{tabular}

Table 7 depicts an apparent variance between the two group averages in all the skills assessed by the systemic thinking assessment. The experimental group had the following averages (3.79 and 2.18 and 4.82 and 2.50) across all skills, respectively, whereas the control group had the following averages (1.83 and 1.00 and 2.30 and 1.10) across all skills, respectively. The Wilk's lambda tests were performed at a significance level of $\alpha=0.003$ to determine whether a statistically significant variance exists between the averages of the two groups. The results of the analysis are presented in Table 8.

Table 8: Wilk's Lambda Test Results for the Variance between Academic Achievements of the Two Groups in All the Skills Assessed by the Post-learning Systemic Thinking Assessment

\begin{tabular}{|l|l|l|l|l|}
\hline Sig. & Df & F-test & Wilk's lambda & Variable \\
\hline 0.003 & 4.000 & 25.945 & 0.346 & Teaching Strategy \\
\hline
\end{tabular}

Table 8 shows a statistically significant variance between the academic achievements of the two groups in all the skills assessed by the post-learning systemic thinking assessment. The multivariate analysis of covariance (MANCOVA) was performed considering the F-test value (5.683) at the $\alpha=0.003$ significance level and to identify the variance in specific skills. The results of the analysis are presented in Table 9.

Table 9: MANCOVA for the Academic Achievement of the Two Groups in All Skills Assessed by the Post-learning Systemic Thinking Assessment

\begin{tabular}{|c|c|c|c|c|c|c|c|c|}
\hline $\begin{array}{l}\text { Wilks' } \\
\text { Lambda }\end{array}$ & \begin{tabular}{|c|} 
Eta \\
Squared
\end{tabular} & Sig. & F & MM & Df & SS & Skill & $\begin{array}{l}\text { Source of } \\
\text { Variation }\end{array}$ \\
\hline \multirow{4}{*}{0.236} & & 0.005 & 8.533 & 11.893 & 1 & 11.893 & $\begin{array}{l}\text { Dissecting } \\
\text { Primary } \\
\text { Systems }\end{array}$ & \multirow{4}{*}{$\begin{array}{c}\text { Dissecting } \\
\text { Primary Systems } \\
\text { Pre-learning }\end{array}$} \\
\hline & & 0.481 & 0.502 & 0.215 & 1 & 0.215 & $\begin{array}{l}\text { Understanding } \\
\text { Relationships }\end{array}$ & \\
\hline & & 0.463 & 0.545 & 1.286 & 1 & 1.286 & $\begin{array}{c}\text { Bridging Gaps } \\
\text { Within Systems }\end{array}$ & \\
\hline & & 0.120 & 2.497 & 2.277 & 1 & 2.277 & $\begin{array}{l}\text { Synthesising } \\
\text { Components }\end{array}$ & \\
\hline \multirow{3}{*}{0.764} & & 0.705 & 0.145 & 0.202 & 1 & 0.202 & $\begin{array}{l}\text { Dissecting } \\
\text { Primary } \\
\text { Systems }\end{array}$ & \multirow{3}{*}{$\begin{array}{l}\text { Understanding } \\
\text { Relationships } \\
\text { Pre-learning }\end{array}$} \\
\hline & & 0.000 & 33.930 & 14.505 & 1 & 14.505 & $\begin{array}{l}\text { Understanding } \\
\text { Relationships }\end{array}$ & \\
\hline & & 0.520 & 0.419 & 0.988 & 1 & 0.988 & $\begin{array}{l}\text { Bridging Gaps } \\
\text { Within Systems }\end{array}$ & \\
\hline
\end{tabular}




\begin{tabular}{|c|c|c|c|c|c|c|c|c|}
\hline & & 0.424 & 0.650 & 0.592 & 1 & 0.592 & $\begin{array}{l}\text { Synthesising } \\
\text { Components }\end{array}$ & \\
\hline \multirow{4}{*}{0.549} & & 0.144 & 2.189 & 3.051 & 1 & 3.051 & $\begin{array}{c}\text { Dissecting } \\
\text { Primary } \\
\text { Systems }\end{array}$ & \multirow{4}{*}{$\begin{array}{c}\text { Bridging Gaps } \\
\text { Within Systems } \\
\text { Pre-Learning }\end{array}$} \\
\hline & & 0.264 & 1.270 & 0.543 & 1 & 0.543 & $\begin{array}{c}\text { Understanding } \\
\text { Relationships }\end{array}$ & \\
\hline & & 0.027 & 5.114 & 12.069 & 1 & 12.069 & \begin{tabular}{|c|} 
Bridging Gaps \\
Within Systems
\end{tabular} & \\
\hline & & 0.205 & 1.645 & 1.500 & 1 & 1.5 & $\begin{array}{l}\text { Synthesising } \\
\text { Components }\end{array}$ & \\
\hline \multirow{4}{*}{0.835} & & 0.598 & 0.282 & 0.393 & 1 & 0.393 & $\begin{array}{l}\text { Dissecting } \\
\text { Primary } \\
\text { Systems }\end{array}$ & \multirow{4}{*}{$\begin{array}{c}\text { Synthesising Pre } \\
\text { learning } \\
\text { Components }\end{array}$} \\
\hline & & 0.499 & 0.463 & 0.198 & 1 & 0.198 & \begin{tabular}{|c|} 
Understanding \\
Relationships
\end{tabular} & \\
\hline & & 0.547 & 0.367 & 0.865 & 1 & 0.865 & \begin{tabular}{|c|} 
Bridging Gaps \\
Within Systems
\end{tabular} & \\
\hline & & 0.004 & 9.184 & 8.376 & 1 & 8.376 & $\begin{array}{l}\text { Synthesising } \\
\text { Components }\end{array}$ & \\
\hline \multirow{12}{*}{0.346} & 0.310 & 0.000 & 26.021 & 36.270 & 1 & 36.27 & $\begin{array}{c}\text { Dissecting } \\
\text { Primary } \\
\text { Systems }\end{array}$ & \multirow{4}{*}{$\begin{array}{l}\text { Teaching } \\
\text { Strategy }\end{array}$} \\
\hline & 0.288 & 0.000 & 23.463 & 10.030 & 1 & 10.03 & $\begin{array}{l}\text { Understanding } \\
\text { Relationships }\end{array}$ & \\
\hline & 0.304 & 0.000 & 25.354 & 59.835 & 1 & 59.835 & \begin{tabular}{|c|} 
Bridging Gaps \\
Within Systems
\end{tabular} & \\
\hline & 0.298 & 0.000 & 24.650 & 22.481 & 1 & 22.481 & $\begin{array}{l}\text { Synthesising } \\
\text { Components }\end{array}$ & \\
\hline & & & & 1.394 & 58 & 80.845 & $\begin{array}{l}\text { Dissecting } \\
\text { Primary } \\
\text { Systems } \\
\end{array}$ & \multirow{4}{*}{ Error } \\
\hline & & & & 0.428 & 58 & 24.796 & $\begin{array}{l}\text { Understanding } \\
\text { Relationships }\end{array}$ & \\
\hline & & & & 2.360 & 58 & 136.876 & \begin{tabular}{|c|} 
Bridging Gaps \\
Within Systems
\end{tabular} & \\
\hline & & & & 0.912 & 58 & 52.895 & $\begin{array}{l}\text { Synthesising } \\
\text { Components }\end{array}$ & \\
\hline & & & & & 63 & 167 & $\begin{array}{c}\text { Dissecting } \\
\text { Primary } \\
\text { Systems }\end{array}$ & \multirow{4}{*}{ Corrected Total } \\
\hline & & & & & 63 & 63 & $\begin{array}{l}\text { Understanding } \\
\text { Relationships }\end{array}$ & \\
\hline & & & & & 63 & 250.734 & \begin{tabular}{|c} 
Bridging Gaps \\
Within Systems
\end{tabular} & \\
\hline & & & & & 63 & 96.438 & $\begin{array}{l}\text { Synthesising } \\
\text { Components }\end{array}$ & \\
\hline
\end{tabular}

Table 9 depicts an F-test value (26.021) at a $\alpha=0.000$ significance level in relation to the teaching strategy for dissecting primary systems to subsystems, (23.463) for understanding relationships within systems, (25.354) for bridging gaps within systems, and (24.650) for synthesising systems from their components. This indicates a statistically significant variance in the average academic achievement 
of the two groups across all four skills assessed by the post-learning systemic thinking assessment. The corrected means for the academic achievement of the two groups were calculated to specify which group was favoured by the variance, the results are exhibited in Table 10.

Table 10: Corrected Mean and Standard Error for the Academic Achievement of the Two Groups across All Skills Assessed by the Post-learning Systemic Thinking Assessment

\begin{tabular}{|c|c|c|c|c|c|}
\hline $\begin{array}{l}\text { Std. } \\
\text { err. }\end{array}$ & $\begin{array}{r}\text { Corrected } \\
\text { Mean }\end{array}$ & Max & No. & Group & Skill \\
\hline 0.22 & 3.69 & \multirow[t]{2}{*}{6} & 34 & Experimental & \multirow{2}{*}{$\begin{array}{r}\text { Dissecting Primary } \\
\text { Systems }\end{array}$} \\
\hline 0.23 & 1.95 & & 30 & Control & \\
\hline 0.12 & 2.05 & \multirow[b]{2}{*}{3} & 34 & Experimental & \multirow{2}{*}{$\begin{array}{r}\text { Understanding } \\
\text { Relationships }\end{array}$} \\
\hline 0.13 & 1.14 & & 30 & Control & \\
\hline 0.28 & 4.68 & \multirow{2}{*}{7} & 34 & Experimental & \multirow{2}{*}{ Bridging Gaps } \\
\hline 0.30 & 2.46 & & 30 & Control & \\
\hline 0.18 & 2.48 & \multirow[b]{2}{*}{4} & 34 & Experimental & \multirow{2}{*}{$\begin{array}{l}\text { Synthesising } \\
\text { Components }\end{array}$} \\
\hline 0.19 & 1.12 & & 30 & Control & \\
\hline
\end{tabular}

Table 10 presents that the experimental group had the following averages (3.69 and 2.05 and 4.68 and 2.48), respectively, across all skills, whereas the control group scored 1.95 and 1.14 as well as 2.46 and 1.12, respectively, across all skills. This indicates that the variance is in favour of the experimental group which, in turn, confirms the effectiveness of a WebQuest strategy-based learning environment in acquiring systemic thinking skills by pre-service teachers in the biology course. The eta-squared values were 0.310 for dissecting systems into subsystems, 0.288 for understanding relationships within systems, (0.304) for bridging gaps within systems, and (0.298) for synthesising systems from their components. These values confirm the findings in this table represent the scale of the impact of the teaching strategy as well as showcase the percentages of variation across all the assessed skills as a result of the teaching strategy.

\section{Discussion}

The results of this study demonstrate the effectiveness of the WebQuest strategybased learning environment in acquiring biological concepts and all the skills of systemic thinking in favour of the experimental group which was taught the biology course using this method. This proves that the implementation of WebQuests led to a better understanding of biological concepts in topics such as ant reproduction, cell division, organism classification, and human body systems, aligning with the findings of Ikpeze and Boyd (2007), Ismael and Abdo (2008), and Salih (2014). This study was distinguished from Salih's 2014 study as it was for a chemistry course for high school students and aimed at developing reflective thinking and achievement. Similarly, Ismael and Abdo's (2008) study sought to develop general thinking methods and the trend towards using them, while the current study attempted to target undergraduate students in acquiring biological concepts and systemic thinking in the life science course. 
This result may be explained if one considers the possibility that WebQuests may have reduced the level of required abstraction which is a feature of the biological concepts from the biology course in question. Concepts such as plant reproduction and cell division and processes such as cell transport, cell breathing, and photosynthesis are abstract in nature. They require forming visualisations and mental models of how they occur in order to understand them. Relying solely on verbal explanations and still pictures is not an easy task for students. This is especially true for topics processed within cells, which were introduced to students through videos on the internet, thus, facilitating the formation of visual models and focusing efforts on following the processes in action. This is in line with Zuckerman's (1994) findings on the positive impact of visual illustrations and models for phenomena that cannot be seen while understanding abstract concepts and processes. Students strive to understand them by forming mental models that may be incomplete. WebQuests assist in demonstrating the relationships between components and the sequence of processes, helping students in visualisation, comprehension, memorising, and systemic thinking. This resulted in pre-service teachers understanding biological concepts and developing their systemic thinking. WebQuests engaged students and focused their attention on biological concepts one at a time. Students were able to control them by pausing, playing, and replaying as required. Pictures, colours, and animation help with concentration, attention, and linking the parts of a system which led to a better linking of biological concepts related to reproduction, meiosis, mitosis, organism classification, and human body systems such as the circulatory and respiratory systems. Consequently, information was securely stored, thereby resulting in better internalisation of the information into the longterm memory, better learning, and development of systemic thinking, aligning to the with the findings of Badmus et al. (2019)

WebQuests provided entertaining websites which helped pre-service teachers understand biology topics in a collaborative and interactive environment. Through an element of interest, they take into consideration various learning styles by diversifying sources of information to develop thinking in general and, especially, systemic thinking. The WebQuest strategy contains various teaching methods relying on students' efforts. At the beginning of a lecture through Microsoft Teams, learning is individualised, then students merge in collaborative groups and collect task-relevant information, analyse the information, and use it to reach a conclusion. The Zunal website supplies enriching software for topics such as reproduction, meiosis, mitosis, organism classification, and human body systems such as the circulatory and respiratory systems, further deepening students' knowledge. Moreover, social media sites birthed an interactive environment where students learn by way of discussions and comments. The satisfaction and comfort levels were high after the experience of learning by WebQuests through the university platform, Microsoft Teams, and Zunal, encouraging the implementation of this strategy for better learning of science at the undergraduate level.

\section{Conclusion}

The WebQuest strategy appeal and innovation led to students developing and strengthening thinking skills, ensuring the retrieving of previous learning, and 
linking knowledge to the reality of their lives, utilised exceptionally during the pandemic. Additionally, it aided the development of systemic thinking skills, storing the scientific material after learning them. The nature of the educational material prepared in the educational environment based on the strategy explains the steps of implementation by text, sound, and image, with links to video clips arousing the students' desire to compete, apart from the logical and sequential organisation of their skills. It gave them the freedom to train and practice them, with the ability to ponder carefully and comprehensively, as well as to define the main purpose of knowledge, link its parts to each other, and analyse the related information. Further, they were able to reorganise these parts through the educational tasks performed. The cognitive theory of multimedia learning employed in the WebQuest strategy - is built on the assumption that the learner in purposeful learning builds his own cognitive images by creating a system for processing visual information and a second system for processing verbal information. By selecting verbal and visual information presented to him and organising it in a meaningful form by building connections between the visual and verbal system, he then merges his mental perceptions by linking the two systems.

\section{Recommendations:}

- Science teachers can use the WebQuest strategy, within an educational environment in teaching biology concepts; because of their great effectiveness in acquiring scientific concepts and developing systemic thinking skills among students;

- Study the material obstacles that teachers may face in using the WebQuest strategy in schools, such as the infrastructure equipment for school laboratories and the existence of rapid internet communication connected to the computers in the laboratory.

\section{References}

Abd, E. H., \& Mohammad, H. A. (2017). The effect of cyclical inquiry in systemic thinking for $5^{\text {th }}$ grade scientific stream students in biology. Qadisiyyah Journal of Literature and Educational Science, 238-275.

Afana, E., Abu, M., \& Mohammad, S. (2007, Sep, 14). The effect of using some constructivist approach strategies in developing systems thinking in engineering among ninth grade students in Gaza [Paper presentation]. The first scientific conference of the Faculty of Education, Al-Aqsa University, Palestine.

Amini, M., Asgari, M., \& Asgari, Z. (2020). Advantages and disadvantages of using Webquests in junior high school English classes in Iran. Journal of Critical Studies in Language and Literature, 1(1), 47-55. https://doi.org/10.46809/jcsll.v1i1.4

Al-Aklouk, A. M. (2010). The effect of an electronic play of the programming language, Visual Basic, on the development of systems thinking skills among tenth-grade students [MA thesis]. Islamic University.

Al-Ghamdi, M. S., \& Al-Afshi, E. A. (2018). Effectiveness of a participatory e-learning environment on developing critical thinking for faculty of education students at Princess. The Journal of the Islamic University for Educational and Psychological Studies, 83-105. 
Al-Kamel, H. (2004). Systems thinking [Paper presentation]. The Fourth Arab Conference on the systemic approach to teaching and learning, Science Teaching Development Centre, Ain Shams University, Egypt.

Ali, S. (2009). The degree of adoption of the concepts of systemic thinking in Saudi public universities from the point of view of the deans and departmental heads in those Universities. Education Journal, 33(4).

American Association for the Advancement of Science (AAAS). (1993). Benchmarks for science literacy. Oxford University Press.

Arnold, R. D., \& Wade, J. P. (2015). A definition of systems thinking: A systems approach [Paper presentation]. Conference on Systems Engineering Research, Procedia Computer Science, 44, 669-678. https:// doi.org/10.1016/j.procs.2015.03.050

Arthur, G., \& Steaven, S. (2015). Relationship between manager strategic thinking and demographic variables and good qualities. Human Resource Management, 5(2), 121-138.

Assaraf, O., \& Orion, N. (2010). System thinking skills at the elementary school level. Journal of Research in Science Teaching, 47(5), 540-563. https://doi.org/10.1002/tea.20351

Badmus, S., Bello, G., Hamzat, A., \& Sulaiman, M. (2019). Effects of WebQuest on secondary school biology students achievement in cell division in Ilorin. Humanities and Social Sciences Letters, 2(7), 64-73. https://doi.org/10.18488/journal.73.2019.72.64.73

Bayram, D., Kurt, G., \& Atay, D. (2019). The implementation of WebQuest supported Critical thinking instruction in pre-service English teacher education: The Turkish context, Participatory Educational Research, 6(2), 144-157. https://doi.org/10.17275/per.19.18.6.2

Dodge, B. (1995). WebQuests: A technique for internet-based learning. Distance Educator, $1(2), 0-13$.

Dodge, B. (1997, November 15). Some thoughts about WebQuests. http://webquest.org/sdsu/about_webquests.html

Dodge, B. (2001). Focus: Five rules for writing a great WebQuest. Learning and Leading with Technology, $28(8), 6-9$. https://edisciplinas.usp.br/pluginfile.php/326587/mod_resource/content/0/F OCUS_Five_Rules_for_Writing_a_Great_WebQuest.htm

Dodge, B. (2011). Five Rules for Writing a Great WebQuest. Learning \& Leading with Technology, 28(8), 285-294.

Fargoun, K. M. (2014, March. 11). WebQuests via internet - Suggested model [Paper presentation]. International Conference on E-Learning in the Arab World on Participatory Learning in the Internet Community, Cairo, Egypt.

Hassanien, A. (2006). Using Webquest to support learning with technology in higher education. Journal of Hospitality, Leisure, Sport and Tourism Education, 5(1), 41-49. https://doi.org/10.3794/johlste.51.96

Ikpeze, C., \& Boyd, F. (2007). Web-based inquiry learning: Facilitating thoughtful literacy with WebQuests. The Reading Teacher, 60(7), 644-654. https://doi.org/10.1598/rt.60.7.5

International Society for Technology in Education (ISTE). (2020). Make WebQuests even easier with premade templates. https://www.iste.org/ 
Ismael, W. A., \& Abdo, Y. B. (2008). Effect of using WebQuests in teaching science on developing thinking styles and tendency to use them by faculty of education students. Education and Psychology Studies Arabic Journal, 2(1), 1-53.

Jacqueline, L. (2007). Confronting challenges in online teaching: The web quest solution. Merlot Journal of Online Learning and Teaching, 3(1). https://jolt.merlot.org/vol3no1/burchum.pdf

Judi, M. (2004). Living systemic thinking: Exploring quality in first-person action research. Sage Journal, 2(3), 305-325. https:/ / doi.org/10.1177/1476750304045945

Jumaa, A., \& Ahmad, Y. (2012). The effectiveness of teaching organic chemistry using the web quest strategy in the achievement of third stage students. Al-Fath Magazine, (49), 62-97.

Gurgil, F., Unal, M., \& Aksoy, B. (2019). Social studies preservice teachers' views on and experiences with WebQuest. Journal of Education and Training Studies, 7(4), 131141. https://doi.org/10.11114/jets.v7i4.4061

March, T. (2003). The learning power of Webquests. Educational Leadership, 61(4), 42-47. https://tommarch.com/writings/ascdwebquests/

March, T. (2004). What WebQuests are (Really). The Fulcrum for Systemic Curriculum Improvement. http:/ / bestwebquests.com/what_webquestsare. asp

McNamara, C. (2006). Field guide to consulting and organizational development: A collaborative and systems approach to performance, change and learning. Authenticity Consulting.

Mitchell, C. (2003). Using WebQuests as a guide and teaching the use of search engines in an 8th grade middle school classroom to improve student learning and increase student comfort when using the internet [MA project]. Graduate Division of Wayne State University Detroit, Michigan.

National Council for Curriculum and Assessment (NCCA). (2020). Curriculum assessment and ICT in the Irish context: A discussion paper. https://ncca.ie/en/resources/curriculum_assessment_and_ict_in_the_irish_context_a_discussion_paper

Odom, A. L. (1995). Secondary \& college biology students' misconceptions about diffusion \& osmosis. The American Biology Teacher, 57, 409-415. https://doi.org/10.2307/4450030

Ossimitz, G. (2014). Systemic thinking in the context of education for sustainable development [Ph.D thesis]. University of Freiburg, Germany.

Ralph, M., Collen, S., Franklin, T., Gerlorich, J., \& McElroy, D. (2008). Teaching science for all children: An inquiry cpproach: (With my education lab) (5th ed.).

Quinn, C., \& Wild, M. (1998). Implications of educational theory for design of instructional multimedia. British Journal of Educational Technology, 29(1), 73-82. https:// doi.org/10.1111/1467-8535.00047

Salih, S. M. (2014). The effectiveness of WebQuests over the internet for teaching chemistry in the development of reflective thinking and academic achievement among high school students. Journal of Arab Studies in Education and Psychology, 2(45), 127-178.

Sarid, A. (2013). Systematic thinking on dialogical education. Journal of Educational Philosophy and Theory, 44(9), 926-941. https://doi.org/10.1111/j.14695812.2011.00757.x

She, H. C. (2002). Concepts of higher hierarchical level require more dual situational learning events for conceptual change: A study of students' conceptual changes on air pressure and buoyancy. International Journal of Science Education, 24(9), 981996. https://doi.org/10.1080/09500690110098895 
Siam, B. A. (2017). The effect of employing the CABRI 3D program in developing the skills of systemic thinking in engineering among the eighth grade female students in Gaza. [MA Thesis]. Islamic University, Gaza, Palestine.

Stephen, G. (2009). Total system thinking. Beverage Industry, 100(4), 55-56.

Ulu, H., \& Ulusoy, M. (2019). The development of metacognitive awareness of reading strategies through WebQuest based teaching. Journal of Education and Instruction, 9(3), 765-818. https://doi.org/10.14527/pegegog.2019.025

Yang, E. M., Andre, T., Greenbow, J., \& Tibell, L. (2003). Spatial ability and the impact of visualization/animation on learning electrochemistry. International Journal of Science Education, 3(25), 329-349. https://doi.org/10.1080/09500690210126784

Zlatkovska, E. (2010). WebQuests as a constructivist tool in the EFL teaching methodology class in a university in Macedonia. CORELL: Computer Resources for Language Learning, 3, 14-24.

Zuckerman, J. T. (1994). Problem solvers' conceptions about osmosis. The American Biology Teacher, 56, 22-25. https:// doi.org/10.2307/4449737

Zuytoon, A. (2007). Constructivism theory and science teaching strategies. Shorouq publishing and distribution house. 